\title{
Factors Affecting the Understanding of IFRS in Accounting Students
}

\author{
Ira Septriana ${ }^{1} \&$ Fuad $^{2}$ \\ ${ }^{1} \mathrm{Ph} . \mathrm{D}$ Scholar at Universitas Diponegoro, Universitas Dian Nuswantoro, Indonesia \\ ${ }^{2}$ Universitas Diponegoro, Indonesia \\ Correspondence: Ira Septriana, Universitas Dian Nuswantoro, Jl. Naluka I No. 5-11, Semarang 50131, Indonesia.
}

Received: November 13, 2019

Accepted: June 25, 2020

Online Published: June 30, 2020

doi:10.5430/ijhe.v9n4p302

URL: https://doi.org/10.5430/ijhe.v9n4p302

\begin{abstract}
This study examines the effect of learning readiness, learning experiences, learning behavior and teaching quality of lecturers on The International Financial Reporting Standard (IFRS) understanding in accounting students. This study uses primary data by distributing questionnaires to accounting program students at Dian Nuswantoro University Semarang. The population in 2019 with the number of students taking their $7^{\text {th }}$ semester in this study was 184 students. Determination of the number of samples in this study using the Slovin formula, to get a total sample of 65 students. The results show that only the readiness of learning affects the understanding of IFRS in accounting students. While the learning experience, learning behavior and teaching quality of lecturers do not affect the understanding of IFRS in accounting students.
\end{abstract}

Keywords: learning readiness, learning experience, learning behavior, lecturer teaching quality and IFRS understanding

\section{Introduction}

Financial statements are prepared based on accounting standards. Accounting standards of each country have differences, the cause is partly due to the economic environment, political environment and accounting theories that exist in these countries. The differences will make it difficult for users of financial statements who have businesses in different countries. To make it easier to understand financial statements, the same Accounting Standards are needed. Because of this, the IFRS (International Financial Reporting Standards) Convergence emerged.

IFRS has received 132 jurisdictions in the world as a set of global accounting standards (IASB, 2017). Capital market players and investors in more than half the world's countries compile their financial statements based on IFRS. With the widespread adoption of IFRS, it is proven that IFRS is the most prominent accounting standard and needs to hope to make the accounting information compiler produce financial reports that are comparable and free of bias (Han et al., 2019). So IFRS can become an International Accounting Standard used by companies on an international scale.

Based on research by Barth et al., (2008) examining applying International Accounting Standards (IAS) relating to higher quality accounting. Implementing an IAS reflects the combined effects of the features of the financial reporting system, including standards, interpretation, law enforcement, and litigation. Researchers found that companies implementing IAS from 21 countries generally showed fewer earnings management, more timely recognition of losses and more value relevance from accounting amounts than matched sample companies that applied non-U.S. domestic standards. The difference in accounting quality between the two groups of companies in the period before the IAS company adopted the IAS did not account for differences in post-adoption. Companies that carry out IAS are generally evidence of improved accounting quality between the pre and post-adoption periods.

IASB (International Accounting Standards Board) which is an international body that handles accounting developments and standards issues IFRS. Indonesia as a member of the G-20 must comply with the agreement to carry out IFRS Convergence. IFRS convergence itself has a goal that corporate financial information can improve quality, especially companies listed on the Stock Exchange.

Indonesia implemented IFRS Convergence in stages, starting from 2008 to 2011. There were 3 stages, namely: (1) First Stage, 2008-2010 was the adoption stage; (2) Second Phase, 2011 is the last preparation stage, and (3) Third Phase, 2012 is the stage of PSAK-IFRS implementation and comprehensive evaluation.

According to Immanuar (2011), changing PSAK to IFRS is not easy. However, IFRS becomes a compulsory competency for Public Accountants, Professional Appraisers, Management Accountants, Regulators and Educator 
Accountants, by adopting IFRS as a single global accounting standard, Indonesian companies will be ready and able to conduct transactions, including mergers and acquisitions ( $\mathrm{M}$ and $\mathrm{A}$ ) across countries.

IFRS in Indonesia also requires accountants and auditors to have enough knowledge of the company's economic and business activities and transactions fundamentally before conducting an assessment. Besides, accountants must also understand the ethical and legal implications in implementing standards because financial reporting information is the main life in the capital market (Carmona \& Trombetta, 2008). The benefits of implementing IFRS will make it easier for investors to invest their capital through the capital market because it uses international standard financial reports (Suprasto, 2015).

Starting in 2012 PSAK applies IFRS. To update the material to suit IFRS requires the role of a tertiary institution. Universities and colleges must force each of their students to understand IFRS to produce competent graduates, although not all university graduates will work in companies that carry out IFRS.

Internal and external factors influence the understanding of IFRS. Internal factors include; Learning Readiness, Learning Experiences and Learning Behavior. While the external reason is the Quality of Teaching of Lecturers.

Kurniawan (2012) has researched about IFRS with the title Student Understanding Level IFRS. Abdullah and Astuti (2012) also wrote under the title Factors Affecting IFRS Understanding of Accounting Students at UIN Alauddin Makasar. Christiani (2015) with the title Understanding of Accounting Students towards IFRS (Study at Private Universities in the City of Kupang). Ermawati and Kuncoro (2017) write Factors that Influence the Understanding of IFRS. Based on the background above, the researcher wants to analyze "Factors Affecting IFRS Understanding in Accounting Students".

\section{Literatur Review}

\subsection{Learning Theory and Learning}

Learning theory is trying to describe how humans learn, thus helping us all understand the process of learning. There are three main perspectives in learning theory, namely Behaviorism, Cognitivism, and Constructivism. Basically, the first theory will be complete with the second theory and so on, so that there are variants, main ideas, or figures that cannot be clearly included, including which ones, or even become separate theories. But we don't need to debate this. What is more important for us to understand is which theories are good for certain regions, and which theories are suitable for other regions. Such understanding is important to increase the value of how to do learning.

Learning theory pays attention to how a person influences other people to make the learning process. Degeng (1989) suggested that learning theory is prescriptive, while learning theory is descriptive. Prescriptive means, the purpose of learning theory is to decide the proper learning method/strategy to get optimal results. In other words, the learning theory deals with efforts to control specific variables in learning theory to ease learning. While descriptive means, the purpose of learning theory is to explain the learning process. Learning theory pays attention to how a person learns.

According to Slavin (2014), learning is a process of acquiring abilities that come from experience. Meanwhile, according to Anni (2004) learning is a system in which various interrelated elements form a change in behavior. Learning is a series of activities or activities carried out consciously by someone and result in changes in him. The change is in the form of knowledge or skills based on sensory devices and experience.

\subsection{Understanding of IFRS}

The process of thinking and learning is part of understanding. Learning and thinking are ways you can get understanding. Understanding is a process, deed, and understanding. Djahura (2013) suggests that student understanding can develop if the learning process takes place effectively and efficiently. IFRS understanding is the level of one's understanding of the basis, standards, and conditions of IFRS reporting.

Understanding IFRS is a person's ability to recognize, understand and understand the basic, standard and provisions that apply to IFRS. The level of understanding of IFRS uses measures in the way to which one knows and understands IFRS (Abdullah, 2015). In increasing students' understanding of IFRS, students need a good and correct learning process.

\subsection{Learning Readiness}

Readiness is the overall condition of a person who makes him ready to give a response or answer in a certain way to a situation (Slameto, 2010). Readiness is also thought to influence student learning outcomes.

Learning readiness is one of the conditions students must have. The learning process needs to consider the readiness of learning because the learning process with readiness will make it easier for students to accept and understand the 
material presented by the teacher and can encourage students to give positive responses where the situation will affect learning achievement obtained. According to Slameto (2010) readiness is a prerequisite for later learning.

According to Nurkancana (1986) states that learning readiness has meaning as several levels of development achieved by someone to receive new lessons. Factors that influence learning readiness according to Djamarah (2002) are physical readiness, psychological readiness, and material readiness.

According to Hanifah and Abdullah (2001) learning is a complex business process carried out by a person from not knowing to know, and not understanding to understanding, and so on to get a better behavior change overall due to his interaction with the environment. Learning readiness determines the learning process, so if the learning process is good, the results obtained are also good. If someone says they are ready to learn, then that person will prepare all their needs in learning. According to Widyaningtyas, Sukarmin and Radiyono (2013) that students who have high learning readiness will have high learning achievements.

\subsection{Learning Experience}

According to Tahar (2012), the experience is a process of learning and developing the growth potential of behavior both from formal and non-formal education or as a process that brings someone to a higher behavior pattern. Meanwhile, according to Tyler, the learning experience is not the same as the learning material or activities carried out by the teacher. The term learning experience refers to the interaction between the learner and the external conditions in the environment in which he reacts to the stimuli that come. Learning through active student behavior, that is what they do when they learn, not what the teacher does.

According to Tyler (1949) The term "learning experience" is not the same as the content with which a course deals nor the activities performed by the teacher. The term "learning experience" refers to the interaction between the learner and the external conditions in the environment to which he/she can react. Learning takes place through the active behavior of the student.

This shows that the learning experience is more about the activities or interactions of the learners themselves with the external conditions in the environment. The learning experience in this study is an accounting learning experience, both formal and informal education such as courses and the like. Students who are active on and off campus have a better understanding and are more numerous than those who only attend the lecture process.

\subsection{Learning Behavior}

Learning behavior is an attitude that arises from students in responding to and responding to every teaching and learning activity that occurs, showing their attitude whether enthusiastic and responsible for the learning opportunities given to them. Learning behavior has two qualitative judgments namely good and bad depending on the person who experiences them, to respond well or even indifferently. Learning behavior also talks about the way students learn themselves so that learning behavior is a way or action that has an attitude towards learning techniques carried out by the person himself or others in certain learning situations.

Hastuti (2003) states that learning behavior is a habit, will and learning skills possessed by someone. While Surachmad in Hanifah and Syukriy (2001) stated five things related to good learning behavior, namely: Habits of attending lessons, Habits of stabilizing lessons, Habits of reading books, Habits of preparing written papers, and Habits of facing exams.

\subsection{Lecturer Teaching Quality}

Lecturers are professional educators and scientists with the main task of transforming, developing, and disseminating science, technology, and art through education, research, and community service (Anonim, 2014). Lecturers are human resources in higher education institutions that have a very important role in producing quality students or graduates. Students get a lot of knowledge from lecturers so lecturers must have the best skills, ability, and teaching methods.

Asmawi's research (2005) revealed that lecturers or instructors are one of the factors that can improve the quality of college graduates. Students will depend on the lecturer, how the lecturer brings the lecture material and what material is conveyed will be additional knowledge or new skills for students.

\section{Hypotheses Development}

\section{a. Learning Readiness}

Learning readiness determines the learning process, so if the learning process is good, the results obtained are also good. If someone says they are ready to learn, then that person will prepare all their needs in learning. The readiness will make it easier for students to accept and understand the material delivered by the teacher and can encourage students to give a positive response where the situation will affect the learning achievement obtained. 
Umam and Fakhrudin (2016) concluded that there was an effect of learning readiness on learning outcomes. According to Widiarti (2018) also said that students who have good learning readiness will have good learning outcomes. Based on these arguments, the hypothesis is as follows:

\section{H1: Learning Readiness influences the Understanding of IFRS}

\section{b. Learning Experience}

According to Tyler, the learning experience is not the same as the lessons or activities carried out by the teacher. Learning experiences are not from lessons or educators, but rather the activities or interactions of students themselves with external conditions in their environment. Andjani and Adam (2013) revealed that there is a positive influence between accounting learning experiences on learning achievement. From this description, the hypothesis compiled is as follows:

\section{H2: Learning Experience influences the Understanding of IFRS}

\section{c. Learning Behavior}

Hanifah and Syukriy (2001) revealed that in the learning process learning behavior needs to follow educational goals. Learning behavior with educational goals can use effective and efficient ways so academic achievement can increase. The habit of taking lessons, reading books, visiting the library and the habit of facing exams are matters on learning behavior (Marita et al, 2008). Therefore, with good learning behavior will lead to an understanding of the greatest learning. Conversely, the impact of poor learning behavior will lead to an understanding of lessons that are less than ideal. Based on this argument the hypothesis is as follows:

\section{H3: Learning Behavior influences the Understanding of IFRS}

\section{d. Lecturer Teaching Quality}

Lecturers are human resources in higher education institutions that have a very important role in producing quality students or graduates. Students get a lot of knowledge from lecturers so lecturers must have the best skills, ability, and teaching methods. Asmawi (2005) in his research revealed that one of the factors that can increase tertiary education graduates is to depend on lecturers as teachers and educators. Based on the description, the hypothesis is as follows:

\section{H4: The quality of lecturer teaching influences the understanding of IFRS}

\section{Research Methodology}

The population in this study uses accounting students who are still active at Dian Nuswantoro University, Semarang. While the sampling technique in this study by a random sampling method is a random sampling technique (Indriantoro and Supomo, 1999). Information obtained from the Administration of the Faculty of Economics and Business at Dian Nuswantoro University, the total population in 2019 with the number of students taking their $7^{\text {th }}$ semester in this study was 184 students. The sample used in this study using the Slovin formula, so the number of samples in this study amounted to 65 students.

The type of research data is primary data in the form of experience or characteristics of students as respondents. Researchers used a questionnaire filled out by respondents. So the data used is primary data. To test hypotheses using multiple regression analysis techniques. The multiple regression equation is as follows:

$$
\mathrm{Y}=b 0+b 1 \mathrm{X} 1+b 2 \mathrm{X} 2+b 3 \mathrm{X} 3+b 4 \mathrm{X} 4+e
$$

Information :

$$
\begin{array}{ll}
\mathrm{Y} & =\text { Understanding IFRS } \\
b 0 & =\text { Constant } \\
\mathrm{X} 1 & =\text { Readiness Study } \\
\mathrm{X} 2 & =\text { Learning Experience } \\
\mathrm{X} 3 & =\text { Behavior Learning } \\
\mathrm{X} 4 & =\text { Quality of Teaching Lecturer } \\
b 1,2,3,4 & =\text { coefficient of regression } \\
e & =\text { error term }
\end{array}
$$




\section{Results and Discussion}

Of the 65 accounting students who were respondents in this study, accounting students were 50 women (77\%), men were $15(2.3 \%)$ and those who did not fill 1 were (1.5\%). Accounting students who are 20 years old is 8 people (12.3\%), 21 years old is 47 people ( $72.3 \%)$, 22 years old is 5 people (7.7\%), 23 years old is 4 people

(6.1\%), and 24 years old is 1 people $(1.5 \%)$.

Accounting students from the Natural Sciences Department high school were 33 people $(50.8 \%)$, from the Social Sciences Department high school by 17 people (26.2\%), from the Accounting Vocational School by 8 people (12.3\%), the other Department's Vocational Schools by 6 people (9.2\%) ) and those who did not fill 1 person (1.5\%).

Accounting students who want to become 9 Public Accountants (13.8\%), want to become Accountants Educators 2 people (3.1\%), want to become Management Accountants 6 people (9.2\%), want to become Government Accountants as many as 14 people ( $21.5 \%$ ), want to become Other Professionals as many as 30 people (46.2\%) and who do not fill 4 people $(6.2 \%)$.

\subsection{Validity Test}

The validation of each variable is done with the results of the Pearson Correlations. It shows that all dimensions of the study are declared valid because they already have a value of significance $<0.05$.

\subsection{Reliability Test}

To measure the level of accuracy, accuracy, and accuracy of one's questionnaire answers. This measurement uses the Cronbach Alpha $(\alpha)$ statistical test with a reliable Alpha value $>0.600$. Following the table of reliability test results:

Table 1 Reliability Testing

\begin{tabular}{lllll}
\hline No. & Indicator & Alpa Cronbach Standard Cronbach Alpha Count Information \\
& & & \\
\hline 1 & Learning Readiness (X1) & 0.600 & 0.801 & Reliable \\
2 & Learning Experience (X2) & 0.600 & 0.642 & Reliable \\
3 & Behavior Learning (X3) & 0.600 & 0.822 & Reliable \\
4 & Lecturer Teaching Quality (X4) & 0.600 & 0.867 & Reliable \\
5 & Understanding of IFRS (Y) & 0.600 & 0.886 & Reliable
\end{tabular}

\subsection{Descriptive statistics}

Table 2. Descriptive Statistic

\begin{tabular}{llll}
\hline & mean & Std. deviation & $\boldsymbol{N}$ \\
\hline Readiness Study & 46.12 & 5.713 & 65 \\
Learning Experience & 17.29 & 3.146 & 65 \\
Behavior Learning & 36.25 & 5.350 & 65 \\
Lecturer Teaching Quality & 35.09 & 4.201 & 65 \\
Understanding of IFRS & 49.77 & 4.892 & 65
\end{tabular}

The table above shows that there are 65 respondents. The average value of Learning Readiness is 46.12 and the standard deviation is 5.713. The average value of the Learning Experience is 17.29 and the standard deviation is 3.416. The average value of Learning Behavior is 36.25 and the standard deviation is 5.350. The average value of the teaching quality of lecturers is 35.09 and the standard deviation is 4.201 . While the average value of Understanding IFRS is 49.77 and the standard deviation is 4.892 .

\subsection{Coefficient of Determination}

Based on SPSS output, the adjusted R2 value is 0.278 , which means that the variable Learning Readiness, Learning Experience, Learning Behavior, and Teaching Quality of Lecturers explain IFRS Comprehension variables by 27.8\%, 
and by $72.2 \%$ explained by others outside of regression model.

\subsection{Hypothesis test}

This test aims to see partially or effectively each independent variable on the dependent variable. Perform a T- test by considering the significance value obtained by each variable. The following are the results of the T-test:

Table 3. Hypotheses Testing

\begin{tabular}{llllll}
\hline Model & \multicolumn{2}{l}{$\begin{array}{l}\text { Coefficients } \\
\text { unstandardized }\end{array}$} & $\begin{array}{l}\text { standardized } \\
\text { Coefficients }\end{array}$ & T & Sig. \\
\cline { 2 - 7 } & $B$ & Std. Error & beta & & \\
\cline { 2 - 5 } (Constant) & 28.969 & 4.935 & & 5.87 & 0 \\
Readiness Study & 0.452 & 0.153 & 0.528 & 2.963 & $\mathbf{0 . 0 0 4}$ \\
Learning experience & -0.009 & 0.201 & -0.006 & -0.046 & 0.964 \\
Behavior Learning & -0.017 & 0.159 & -0.019 & -0.107 & 0.915 \\
Lecturer Teaching Quality & 0.02 & 0.209 & 0.018 & 0.098 & 0.922
\end{tabular}

$\mathrm{H} 1$ test results are Readiness Learning gets a significance value of $0.004<0.05$ and the $t$ value is 2.963 . This shows that Learning Readiness influences IFRS understanding. Thus, the H1 hypothesis states that Learning Readiness influences IFRS understanding is accept. The level of readiness of learning the higher the better the understanding of students about IFRS. High learning readiness means that students are ready to learn, so everything related to learning will be ready. Everything is in the form of facilities, physical, mental, environmental and behavioral so that the results of the learning process are achieved. Students with high levels of learning readiness will be able to take part in learning activities properly and can develop their skills. The results of this study are in line with the study of Widyaningtyas (2013) and Abdullah (2015) that students who have high learning readiness will have high learning achievements as well.

$\mathrm{H} 2$ test results showed that the learning experience got a significance value of $0.964>0.05$ and the $t$ value -0.046 . So it shows if the Learning Experience does not affect IFRS understanding. Thus, the hypothesis $\mathrm{H} 2$ expressing Learning Experience affects the understanding of IFRS rejected. The learning experience based on the results of the study here does not affect the understanding of accounting students about IFRS. Because the learning experience here is a learning experience that is not related to IFRS material. The experience here is such as attending seminars and courses but they are not related to IFRS material. Besides students when attending courses or seminars do not carry out well and lack focus. Only as an obligation. Besides this study uses a sample of last year students so that material about IFRS has long been obtained. IFRS material is given in the early semester of lectures so that the student who became the respondent forgot about the IFRS material. Because last year students focus more on internships, final assignments or thesis. This is not consistent with the research of Lestari and Suparlinah (2010), which states that learning experiences do not much affect the introduction of accounting values.

$\mathrm{H} 3$ test results indicate that Behavior Learning gets a significance value of $0.915>0.05$ and $t-0.107$. So it shows if Behavior Learning does not affect IFRS understanding. Thus, the H3 hypothesis that revealed Learning Behavior influencing IFRS understanding was rejected. Examples of learning behavior are habits in learning, reading habits, visiting the library and study habits when facing exams. Students tend to have different habits. In addition to these behaviors and habits, students have other things to consider. Namely awareness in doing assignments and attending college is still lacking, so learning activities are interpreted as an obligation and not a need to learn. Also in this study using the last year's students allegedly, the students were not ready with questions about IFRS material. Because IFRS material is accepted in the early semester. The results of this study are not in line with the research of Hanifah and Abdullah (2001) and Abdullah (2015).

The results of the $\mathrm{H} 4$ test are the Quality of Teaching Lecturers to get a significance value of $0.922>0.05$ and the value of $t$ is 0.098 . So the Quality of Lecturer Teaching does not affect the understanding of IFRS. Thus, hypothesis H4 states that the Lecturer Teaching Quality affecting IFRS understanding is rejected. Lecturers have an important role in the lecture process. Lecturers who have good teaching quality and are competent in their field can produce quality students. But student success is not determined by lecturers alone. Many factors determine the success of a student. If you have qualified lecturers in teaching and are competent in the field of accounting but if you have students who do not want to 
learn and try to learn, then the results of their learning are also unsatisfactory. It can also occur if students are not focused and busy with themselves when the lecturer explains, so as good as any lecturer, then if students do not focus on listening and busy with themselves, the results of the study are not satisfactory. The results of this test do not support the research of Sari (2011), Asmawi (2005), Lestari and Suparlinah (2010), and Abdullah (2015) that the quality of teaching affects the level of understanding of accounting students, the value of introductory accounting courses, and improving the quality of college graduates.

\section{Conclusion}

Based on the results of research conducted, so the conclusion is:

1. Learning Readiness influences the Understanding of IFRS. Therefore good or bad Learning Readiness will affect IFRS Understanding. Thus the hypothesis that Learning Readiness influences the Understanding of IFRS is accepted.

2. Learning Experience does not affect IFRS Comprehension. Therefore good or bad Learning Experience will not affect the Understanding of IFRS. Thus the hypothesis which states the Learning Experience influences the Understanding of IFRS is rejected. The Learning experience does not affect because students when taking courses or seminars do not carry out it well and lack focus.

3. Learning Behavior does not affect IFRS Understanding. Therefore good or bad Learning Behavior will not affect the Understanding of IFRS. Thus the hypothesis stating that Learning Behavior influences the Understanding of IFRS is rejected. Learning Behavior does not affect because students work on assignments and attend lectures simply because they regard it as an obligation that does not become a necessity for them.

4. Lecturer Teaching Quality does not affect IFRS Understanding. Therefore, the pros and cons of lecturer teaching quality will not affect IFRS understanding. Thus the hypothesis stating that Lecturer Teaching Quality influences IFRS Comprehension is rejected. Lecturer Teaching Quality does not affect IFRS Understanding because students are not ready to attend lectures, so during lecture hours they are not focused and play their gadgets.

Some suggestions given for further research are as follows:

For further research, it is suggested to add factors that can influence the understanding of IFRS in students.

1. It is suggested to add other variables, namely student motivation and student personality that can influence IFRS understanding.

2. It is suggested to expand the research sample, namely to all accounting students. Because in this study using a sample of 7th-semester students where the student has focused on internships and thesis.

\section{References}

Abdullah, M. Wahyuddin. 2015. Faktor yang Memengaruhi Pemahaman International Financial Reporting Standards (IFRS) pada Mahasiswa Akuntansi UIN Alauddin Makasar, 5(2), Desember 2015: 1-12.

Andjani, S dan H. Adam. 2013. Faktor-Faktor yang Mempengaruhi Prestasi Belajar Mahasiswa Pada Mata Kuliah Pengantar Akuntansi. Jurnal Ilmiah Mahasiswa FEB, 1(1), 1-10. https://doi.org/10.18592/jt.v1i1.159

Anonim, 2014. Dosen Wikipedia the free Encyclopedia. http://id. m.wikipedia.org/wiki/dosen, diakses 29 Agustus.

Anni, Catharina Tri, dkk. 2004. Psikologi Belajar. Semarang : UPT UNNES Press.

Asmawi, R.M. 2005. Strategi Meningkatkan Lulusan Bermutu di PerguruanTinggi. Makara, Sosial Humaniora, 9(3), 66-71. https://doi.org/10.7454/mssh.v9i2.124

Barth, M. E., Landsman, W. R., \& Lang, M. H. (2008). International accounting standards and accounting quality. Journal of Accounting Research, 46(3), 467-498. https://doi.org/10.1111/j.1475- 679X.2008.00287.x

Carmona, S., \& Trombetta, M. (2008). On the global acceptance of IAS/IFRS accounting standards: The logic and implications of the principles-based system. Journal of Accounting and Public Policy, 27(6), 455-461. https://doi.org/10.1016/j.jaccpubpol.2008.09.003

Christiani, Nita Yuningsih. 2015. Pemahaman Mahasiswa Akuntansi terhadap International Financial Reporting Standard (IFRS) studi pada perguruan tinggi swasta di kota Kupang. Tesis. Universitas Kristen Satya Wacana Salatiga.

Degeng, I N. S. (1989). Ilmu Pengajaran Taksonomi Variable. Jakarta: Depdikbud. 
Djahura, D. 2013. Pemahaman Sebagai Pernyataan Hasil Belajar, http://dirman- djahura.blogspot.com/favicon.ico, diakses 12 Desember.

Djamarah Syaiful Bahri. 2002. Strategi Belajar Mengajar. Jakarta : Rineka Cipta

Ermawati, Nanik \& A. Kuncoro. 2017. Faktor-Faktor yang Mempengaruhi Tingkat Pemahaman IFRS (International Financial Reporting Standard). Jurnal STIE Semarang, 1(9). Edisi 1.

Han, Y., Chand, P., \& Mala, R. (2019). Impact of ambiguity tolerance and tertiary education on professional judgment. Accounting Forum. https://doi.org/10.1080/01559982.2019.1569813

Hanifah, S. Abdullah. 2001. Pengaruh Perilaku Belajar Terhadap Prestasi Akademik Mahasiswa Akuntansi.

IASB. (2017). Analysis of use of IFRS standards around the world [Online] Available:. IFRS Foundation [Accessed 27/09/2018].https://www.ifrs.org/use-around-the-world/use-of-ifrs-standards-by- jurisdiction/\#analysis

Indriantoro dkk,. 1999. Metodologi Penelitian Bisnis. Edisi Pertama BPFE. Yogyakarta.

Kurniawan. 2012. Tingkat Pemahaman Mahasiswa terhadap IFRS studi empiris pada mahasiswa Universitas Dian Nuswantoro dan Universitas Katholik Soegijapranata Semarang. Skripsi.

Lestari, P dan I. Suparlinah. 2010. Analisis Faktor-Faktor yang Mempengaruhi Prestasi Akademik Pada Mata Kuliah Pengantar Akuntansi. Jurnal Manajemen dan Akuntansi, 11(2), 144-152.

Nurkancana, Wayan. 1986. Evaluasi Pendidikan. Surabaya: Usaha Nasional

Suprasto, B. (2015). PENERAPAN INTERNATIONAL FINANCIAL REPORTING STANDARD, 11-16.

Slameto. (2010). Belajar dan Faktor-Faktor yang Mempengaruhinya. Jakarta: Rineka Cipta. Slavin, Robert E. 2014. Cooperative Learning: Teori, Riset dan Praktek. Bandung: Nusa Media.

Tahar, F. 2012. Pengaruh Diskriminasi Gender dan Pengalaman Terhadap Profesionalitas Auditor. Skripsi.

Makassar:Fakultas Ekonomi Universitas Hasanuddin, Makassar.

Tyler, R. W. (1949). Basic principles of curriculum and instruction. Chicago, IL: University of Chicago Press. Wasty Soemanto, Psikologi Pendidikan (Jakarta: Rineka Cipta), hlm, 6.

Widyaningtyas, A. Sukarmin \& Y. Radiyono. 2013. Peran Lingkungan Belajar dan Kesiapan Belajar Terhadap.

Prestasi Belajar Fisika Siswa Kelas X Sekolah Menengah Atas Negeri 1 Pati(2013). Jurnal Pendidikan Fisika, 1(1), 136-143. 